AperTO - Archivio Istituzionale Open Access dell'Università di Torino

\title{
Great cormorant predation on Cisalpine pike: a conservation conflict
}

\section{This is the author's manuscript}

Original Citation:

Availability:

This version is available http://hdl.handle.net/2318/1727826

since $2020-02-16 T 17: 24: 44 Z$

Published version:

DOI:10.1007/s10344-015-0951-3

Terms of use:

Open Access

Anyone can freely access the full text of works made available as "Open Access". Works made available under a Creative Commons license can be used according to the terms and conditions of said license. Use of all other works requires consent of the right holder (author or publisher) if not exempted from copyright protection by the applicable law. 


\section{European Journal of Wildlife Research Great Cormorant predation on Cisalpine Pike: a conservation conflict --Manuscript Draft--}

Manuscript Number:

Full Title:

Article Type:

Keywords:

Corresponding Author:
EJWR-D-14-00254R2

Great Cormorant predation on Cisalpine Pike: a conservation conflict

Original Article

Esox cisalpinus; Phalacrocorax carbo sinensis; predation; Italy; wildlife conflict

Stefano Fenoglio, phd

University of Piemonte Orientale

Alessandria, ITALY

Corresponding Author Secondary Information:

Corresponding Author's Institution:

University of Piemonte Orientale

Corresponding Author's Secondary Institution:

First Author:

Giovanni Battista Delmastro

First Author Secondary Information:

Order of Authors:

Giovanni Battista Delmastro

Giovanni Boano

Paolo Lo Conte

Stefano Fenoglio, phd

Order of Authors Secondary Information:

Funding Information:

\section{Abstract:}

In the last decades the distribution and abundance of Great Cormorants have extraordinarily increased throughout Europe. Many studies reported that Great Cormorants may impact fish populations not only by consuming large number of individuals but also by wounding them. Most studies regarded fish farms and cultured species but there is less information about wild fish populations. In this study we examined the incidence of wounds caused by Great Cormorants on an endemic and threatened species, the Cisalpine Pike (Esox cisalpinus Bianco and Delmastro 2011). The object of our research was to quantify this impact, and indirectly to estimate if cormorant predation may be one of the causes of the rapid decline of this Esocidae. In the years 2009-2013, 139 pikes were collected in some gravel pits in North-Western Italy. More than a half of the specimens (57\%) reported wounds attributable to Great Cormorant attacks. Most wounds were localized in the dorsal and lateral surfaces of pikes. We detected a significant difference in the occurrence of wounds between fish sizes, with $73.5 \%$ of adults showing some kind of injury. In a context of general freshwater habitat alteration, quarry lakes represent important sites for Cisalpine Pike conservation. Unfortunately, Pike breeding season overlaps with the presence of large colonies of overwintering Cormorants, increasing the probability of interactions in a period of extreme importance for this Esocidae. Our data evidenced that the increase of Cormorants represent an important menace for Cisalpine Pike conservation. Finally we suggest some management options to minimize the problem. 
Giovanni B. Delmastro ${ }^{1}$, Giovanni Boano ${ }^{1}$, Paolo Lo Conte $^{1}$, Stefano Fenoglio ${ }^{2}$

\title{
Great Cormorant predation on Cisalpine Pike: a conservation conflict
}

${ }^{1}$ Natural History Museum of Carmagnola, via S. Francesco di Sales 188, Carmagnola I-10022, Italy

${ }^{2}$ DISIT, Università del Piemonte Orientale, Via Teresa Michel, Alessandria, I-15121, Italy Corresponding author: e-mail fenoglio@unipmn.it, tel +39 0131 360201, fax: + 390131360243

\begin{abstract}
In the last decades the distribution and abundance of Great Cormorants have extraordinarily increased throughout Europe. Many studies reported that Great Cormorants may impact fish populations not only by consuming large number of individuals but also by wounding them. Most studies regarded fish farms and cultured species but there is less information about wild fish populations. In this study we examined the incidence of wounds caused by Great Cormorants on an endemic and threatened species, the Cisalpine Pike (Esox cisalpinus Bianco and Delmastro 2011). The object of our research was to quantify this impact, and indirectly to estimate if cormorant predation may be one of the causes of the rapid decline of this Esocidae. In the years 2009-2013, 139 pikes were collected in some gravel pits in North-Western Italy. More than a half of the specimens $(57 \%)$ reported wounds attributable to Great Cormorant attacks. Most wounds were localized in the dorsal and lateral surfaces of pikes. We detected a significant difference in the occurrence of wounds between fish sizes, with $73.5 \%$ of adults showing some kind of injury. In a context of general freshwater habitat alteration, quarry lakes represent important sites for Cisalpine Pike conservation. Unfortunately, Pike breeding season overlaps with the presence of large colonies of overwintering Cormorants, increasing the probability of interactions in a period of extreme importance for this Esocidae. Our data evidenced that the increase of Cormorants represent an important menace for Cisalpine Pike conservation. Finally we suggest some management options to minimize the problem.
\end{abstract}

Key-words: Esox cisalpinus; Phalacrocorax carbo sinensis; predation; Italy; wildlife conflict 


\section{Introduction}

The Great Cormorant is present in Europe with two subspecies: Phalacrocorax carbo carbo (Linnaeus 1758) and P. c. sinensis (Blumenbach 1798). The first is mainly sedentary on European Atlantic coasts, while the second inhabits wetlands and breeds in colonies, often with herons, on the trees or at ground. P. c. sinensis is widely distributed across the Palearctic from China to Western Europe (del Hoyo et al. 1992): mainly migratory, overwinters South of $65^{\circ}$, around the Mediterranean basin. The species is markedly gregarious also in the cold season, where some ten to thousands of birds aggregate to roosts overnight.

During the last 30-40 years there has been a large increase in the populations of P.c. sinensis across Europe (Van Eerden and Gregersen 1995; Bregnballe et al. 2003; Steffens 2010). In the past, direct persecution because of its fish eating habits and the massive use of agricultural biocides (in particular chlorinated carbons like PCBs and DDT; Van Eerden and Gregersen 1995) had drastically reduced the populations of this species, leading to its total extinction in most European countries in the 1960s. Since its legal protection in 1965 in the Netherlands (Van Bommel 2003) and after the inclusion by the European Commission in the Annex 1 of the Birds Directive as species of particular conservation interest (79/409/EEC) populations of Cormorants rapidly increased, and nowadays they are much larger and widespread than in previous centuries, with about 1.5-2.0 millions of Great Cormorants at present living in Europe (Van Eerden et al. 2011). Furthermore, in the past Great Cormorants were typical inhabitants of coastal zones and estuaries, while nowadays their exponential growth has led them to colonize all kind of inland waters, from great lakes to ponds and different order lotic systems.

In Piemonte (NW Italy), the Great Cormorant was considered a regular and uncommon migratory and wintering bird (Salvadori 1872) until 1980 (Boano and Mingozzi 1981), then the number grew exponentially from 90 individuals in the winter $1984-85$ to 5200 in the winter 1994-95 in 14 roosts (Alessandria et al. 1999). Afterwards the number leveled at around 4000 (3913 counted in 19992000 in 22 roosts) with 3056 birds counted in 2013. Worth noting that after the mid '90 the 
cormorants were frequently observed also away from the main rivers and lakes, along little stream, channels and in little ponds (Fig. 1). At the same time the number of little roosts augmented, making more difficult to perform accurate censuses. The first breeding attempt in Piemonte was observed in 1989 (Carpegna et al. 1990) and the breeding population reaches now about 600 pairs in 9 colonies (Volponi and CorMoNet.it 2013). Many factors have contributed to this impressive growth, such as broad habitat choice, long lifespan, high survival rate, environmental alterations of aquatic habitats, but the protection of the species has surely played a leading role (Marion and Le Gentil 2006). Like most cormorant species, the Great Cormorant is an opportunistic piscivore, able to exploit most waters, and therefore its increase in numbers has led to conflicts with fisheries (Dieperink 1995; Leopold et al. 1998; Carss 2003; Vetemaa et al. 2010). Each Cormorant ingest on average 4-500 g of fish every day, or even more, and many studies on feeding habits have reported wide trophic range, high adaptability to varying environmental conditions, and an impressive plasticity in the daily amount and size of prey (Gagliardi et al. 2007). Furthermore, apart from direct consumption, Cormorants may affect freshwater fish communities in other indirect ways. First, a percentage of attacked fish is only wounded but not ingested because of the size: they usually report deep and/or surface injuries which often result in diseases and mortality (Adamek et al. 2007; Ondračková et al. 2012). Poór (2005) reported that in lentic habitats the percentage of wounded fish can be high (approximately $0.3-0.4 \mathrm{~kg}$ of fish per cormorant daily), but realistic data on fish wounding by cormorants in the wild are relatively scarce, because most studies have been realized in semi-artificial conditions such as aquaculture areas, fish farms or even experimental mesocosms (Davies et al. 1995; Grémillet et al. 2006; Adamek et al. 2007; Kloskowski 2011).

For these reasons, the growth in both density and distribution of this specialized piscivore predator could represent an important additional threat to local fish faunas, which are already entrenched by the alteration of most aquatic environments. Obviously, these concerns are particularly important in the case of endemic or threatened fish species. 
While the Pike Esox lucius (Linnaeus 1758) is widespread and relatively common over Eurasia and

North America (Kottelat and Freyhof 2007), the Italian population has been recently described as a new species, the Cisalpine or Italian Pike Esox cisalpinus Bianco and Delmastro 2011 on the basis of morphological and genetic peculiarities (Lucentini et al. 2006). In this study we focused on this newly described species, which seems to be extremely localized and threatened. Cisalpine Pike is a primary, moderately cold stenotherm, preferentially limnophilous species, native of the PadanoVeneto district, Tuscany and Latium (Bianco and Delmastro 2011; Bianco 2014).

In Piemonte, area in which is localized the locus typicus of E. cisalpinus, this species inhabits a wide range of still and slow course lowland freshwaters, abounding in aquatic plants and fine sediment substrates (Gandolfi et al. 1991). In all this area, Cisalpine Pike reduced drastically its distribution and, in approximately fifteen years, disappeared from $54 \%$ of the sampled stations (Regione Piemonte 1992, 2006). Main threats are over-fishing, habitat loss and degradation, damage of breeding areas (aquatic vegetation) and introduction of exotic species (Delmastro et al. 2007). With the increasing alteration of natural environments, gravel pit lakes host nowadays a relevant part of the remaining population. The object of our research was to quantify the incidence of Cormorant-related wounds on natural populations of Cisalpine Pike, and indirectly to verify if Cormorant predation can be considered among the causes of the rapid decline of this Esocidae.

\section{Material and methods}

The study area is localized in Piemonte (NW Italy), in a lowland area characterized by many gravel pit lakes located along the Po river. In this area, the massive extraction of gravel and sand started in the early ' 70 and resulted in the realization of a series of man-made lentic environments. Demographical and distributional data about Great Cormorant in this area were obtained from published literature (Alessandria et al. 1999, 2001), census of wintering waterfowl made by Gruppo Piemontese Studi Ornitologi (GPSO) from 1979 to 2008 (Della Toffola et al. unpublished data), and data reported by bird-watchers from 2009 to 2011 on the website "aves.piemonte" (www.regione.piemonte.it/aves). Moreover, specific field researches were conducted in the study 
area with evening count at roosts, spot counts on gravel pit lakes (maximum number of bird feeding or resting in a single lake) and regular field trips (to collect data about local phenology of the birds). Counts were performed in three roosts localized in our study area: roost ' $\mathrm{a}$ ' $\left(44^{\circ} 53^{\prime} 16 \mathrm{~N}^{\circ} 42^{\prime} 21^{\prime}\right.$ ' $\mathrm{E}$,

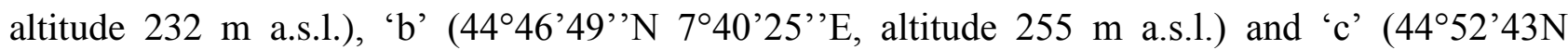
$7^{\circ} 52^{\prime} 02^{\prime}$ 'E, altitude $256 \mathrm{~m}$ a.s.1.). Pikes were collected in five gravel pit lakes located near the Po river, upstream of the city of Torino (Table 1, see more details in Delmastro and Balma 2010). Fish were captured by electrofishing in February-March in the years 2009-2013 (with the exception of a single specimen collected in May and another one in June). Electrofishing is a widely used technique in quantitative studies of freshwater fish (Penczak and Głowacki 2008). All studied specimens belong to the endemic Cisalpine (or Italian) Pike Esox cisalpinus. Fish total length (TL) was measured with an ichthyometer to the nearest lower millimeter (mm). Each fish was accurately examined for Cormorant related wounds, as described by Carss (2003) and Adámek et al. (2007). The presence and localization (dorsal, lateral, ventral, on the head, on the caudal peduncle and fins) of wounds were recorded. For statistical analysis, specimens were grouped in two categories according to their size: juveniles (TL $<30 \mathrm{~cm}$ ) and adults (TL> $30 \mathrm{~cm}$; Gandolfi et al. 1991). To evaluate if significant differences in wound occurrence existed between pikes of different size and sex we performed Mann-Whitney U tests using the software Systat 8.0 (Wilkinson 1992).

\section{Results}

\section{Cormorant}

In the study area two roosts are known (a, b) and another one is localized about $15 \mathrm{Km}$ East. The roost (a) was used by 375-500 birds in 1995-96, but the population dropped to 120 in 2012 and 55 in 2013. The roost (b) was much more stable with 100-120 birds and in the same site a few pairs breed since 2008 (Beraudo and Giammarino 2011). The third roost count 100-150 birds in the last years (139 in 2014). Other roosts in the region are more than $25-30 \mathrm{Km}$ apart of the study area and are not considered here. Spot counts of resting and feeding birds in the gravel pits of the study area during winter (December-March) counted up to 35 (and even 70) cormorants in a single lake and 
averaged 130 (1993-2008) and 65 (2009-2013) over all the gravel pits of the study area. Regarding

monthly abundances, regular counts in the area showed a evident increase of Cormorant presences from summer months to winter period, with a peak during March, in relation to migratory movements (Fig. 2).

Pike

We collected and examined 139 specimens of E. cisalpinus (48 males, 42 females and 49 undetermined, see Table 1 for sample distribution). Mean fish total length was $441 \mathrm{~mm}$ ( $\pm 174 \mathrm{SD})$, with a maximum of $940 \mathrm{~mm}$ and a minimum of $187 \mathrm{~mm}$. More than a half of the specimens $(\mathrm{n}=79$; $57 \%$ ) reported injuries attributable to Great Cormorant attacks. Among these, 64 specimens showed superficial wounds and/or healed scars, 5 subjects showed deep hypodermic wounds while 15 specimens were characterized by both wound types. Considering all data together, injuries were mainly localized in the dorsal (32.3\% of total wounds detected) and lateral surfaces $(28.2 \%)$ of the pikes, interesting caudal peduncle and fins more infrequently (respectively 10.5 and $17.7 \%$ ). In very few occasions injuries were detected in the ventral surface $(9.0 \%)$ or in the head $(5.0 \%)$. No differences were detected between sex (Mann-Whitney $\mathrm{U}$ test $=831.0 \mathrm{p}=\mathrm{n}$.s.), but a significant difference in the occurrence of wounds between the two size categories was detected (MannWhitney U test $=864.5 \mathrm{p}<0.001$ ): only $17 \%$ of juveniles were interested by wounds, while $73.5 \%$ of adults showed some kind of injury (Fig. 3).

\section{Discussion}

More than half of the examined specimens have some type of wounds, nevertheless this percentage may be an underestimation of the Cormorant impacts on this species. In fact, direct underwater observation indicated that Cormorant rarely injuries small size fish without eating them, while the rate of prey loss (and potential injury) might increase with fish size (Grémillet et al. 2006). The significant difference in the wound occurrence between the two size/age classes in our study undoubtedly suggests that attacks towards small subjects $(\mathrm{LT}<30 \mathrm{~cm})$ conclude with an higher success rate, i.e. with effective predation. This agree with previous observations reporting that the 
most commonly foraged fish usually is around 15-25 cm (Jepsen and Olesen 2006; Spairani et al. 2010). In particular, for ingested Pike a mean length of $24 \mathrm{~cm}$ and $37 \mathrm{~cm}$ was respectively observed by Santoul (2005) and Keller (1995).

Our findings are particularly worrying since perifluvial, lentic areas represent one of the last refuges for Pikes, because of the widespread alteration of most lotic environments (Fochetti 2012). The Pike reproductive season falls between the third week of February and mid-April, with a peak in March. In this period, Pikes approach shallower waters, reaching higher densities near breeding areas. Unfortunately, in the same period these environments are also home to the highest concentrations of Cormorants (see Fig. 2): these birds regularly overwinter and forage in quarry lakes, because they never freeze due to their morpho-hydrological characteristics. The possibility of predation on Pike is also enhanced by the fact that during winter months most of Ciprinidae, which abound in shore areas during warm months, are largely absent; in fact, in this season minnows prefer to reach deeper areas of the lake characterized by relatively warmer temperatures.

It is well known that most Pike populations are in strong decline, because excessive fishing pressure, water pollution, anthropic alterations of aquatic environments, especially breeding sites such as lowland springs (Gandolfi et al. 1991). The last IUCN category of E. cisalpinus is still "data deficient" (Rondinini et al. 2013), but it should be classified at least as "vulnerable", as its native populations are threatened and also affected by hybridization and competition with the allochthonous E. lucius (Bianco 2014). Currently, there is an elevate risk of disappearance in the whole distribution area and particularly in the western Po basin (Regione Piemonte 2006; Delmastro et al. 2007), so that recently this species has been considered highly endangered (Forneris et al. 2011).

Our data does not support the hypothesis that Great Cormorants mainly feed on Pike, according with numerous studies reporting that Pike normally accounts for a small percentage of Cormorant food (Beccaria 1998, in Piemonte; Opačak et al. 2004; Santoul 2005). However, also this relatively 
small impact can have dramatic consequences. In facts, our data evidenced that the predation of cormorants can represent an important, additional menace for the conservation of Cisalpine Pike.

The management of cormorant population is matter of great debates and the solutions can be reached only with management efforts realized at continental level.

From 1997 the species was removed from the European Bird Directive (European Commission IP/97/718 of July 30, 1997) and, notwithstanding to be a protected species in most European countries, active control measures with nest destruction, eggs oiling and shooting adults have been undertaken now in many places (Van Eerden et al. 2012). We can hypothesize that the recent reduction of wintering cormorants in NW Italy may be related to these control strategies, particularly of the Danish populations from where about $81 \%$ of the ringed cormorants observed in NW Italy came (Della Toffola et al. 1997). Nevertheless, in a situation of diffuse decline of Cisalpine Pike populations (as reported above), also small number of cormorants can represent an important threat. For this reason, a local management action should be very effective, in particular in artificial habitats as the gravel pits. In this context, a reduction of predations and wounding could be probably obtained by diversifying the habitat morphology and in particular by introducing artificial refuges in the littoral areas (Russel et al. 2008; Puzzi et al. 2012).

\section{Acknowledgements}

We are grateful to A. Parisi, E. Colombino, L. Ghione, G.L. Vaira, M. Fior. P. Tizzani and J. M. Tierno de Figueroa for help and support during different phases of the work. We also thank Fauna and Flora Protection services and Natural Parks of Po river of Torino and Cuneo districts. 


\section{References}

Adámek, Z, Kortan J, Flajshans M (2007) Computer-assisted image analysis in the evaluation of fish wounding by cormorant [Phalacrocorax carbo sinensis (L.)] attacks. Aquacult Int 15:211216.

Alessandria G, Carpegna F, Della Toffola M (1999) Il Cormorano Phalacrocorax carbo nella regione piemontese. Parte I. Analisi storica e situazione attuale (Aves, Phalacrocoracidae). Riv Piem St Nat 20:259-297.

Alessandria G, Carpegna F, Della Toffola M (2001) Il Cormorano Phalacrocorax carbo nella regione piemontese. Parte II. Distribuzione e biologia della popolazione nidificante (Aves, Phalacrocoracidae). Riv Piem St Nat 22:261-280.

Beccaria A (1998) Dieta del Cormorano Phalacrocorax carbo sinensis (Blumenbach, 1798) e impatto sulle popolazioni ittiche. Riv Piem St Nat 18:241-247.

Beraudo PL, Giammarino M (2011) Primi casi di nidificazione del Cormorano Phalacrocorax carbo in Provincia di Cuneo (Piemonte Sud-Occidentale). Picus 71:33-34.

Bianco PG (2014) An update on the status of native and exotic freshwater fishes of Italy. J Appl Ichthyol 30:62-77.

Bianco PG, Delmastro GB (2011) Recenti novità tassonomiche riguardanti i pesci d'acqua dolce autoctoni in Italia e descrizione di una nuova specie di luccio. Res Wildlife Cons 2:1-14.

Boano G, Mingozzi T (1981) Analisi della situazione faunistica in Piemonte. Uccelli e Mammiferi. Piemonte ambiente-fauna-caccia. E.D.A., Torino, Italy.

Bregnballe T, Engström H, Knief W, van Eerden MRT, Van Rijn S, Kieckbusch J, Eskildsen J (2003) Development of the Breeding population of Great Cormorants Phalacrocorax carbo sinensis in The Netherlands, Germany, Denmark, and Sweden during the 1990s. Vogelwelt 124:15-26. 
Carpegna F, Della Toffola M, Alessandria G (1990) Nidificazione di Phalacrocorax carbo sinensis in Piemonte. Riv It Ornitol 60:205-207.

Carss DN (2003) Reducing the conflict between cormorants and fisheries on a pan-European scale: REDCAFE. No. Q5CA-2000-31387, http://www.ceh.ac.uk/redcafe/redcafedocs.htm Accessed 10 June 2014

Cucco M, Levi L, Maffei G, Pulcher C (1996) Atlante degli uccelli di Piemonte e Valle d'Aosta in inverno (1986-1992). Monografie XIX. Museo Regionale Scienze Naturali di Torino, Torino, Italy.

Davies JM, Fektham MJ, Walsingham MV (1995) Fish wounding by cormorants, Phalacrocorax carbo L. Fisheries Manag Ecol 2:321-324.

del Hoyo J, Elliot A, Sargatal J (1992) Handbook of the Birds of the World. Lynx Editions, Barcelona, Spain.

Della Toffola M, Alessandria G, Carpegna F (1997) Origins of ringed Cormorants Phalacrocorax carbo observed in north-western Italy. Suppl Ric Biol Selv 26:409-412.

Delmastro GB, Pascale M, Perosino GC (2007) I pesci del fiume Po in Piemonte: situazione attuale. Riv Piem St Nat 28:275-303.

Delmastro GB, Balma GA (2010) La Savetta Chondrostoma soetta (Osteichthyes, Cyprinidae) nei laghi di cava della fascia fluviale del Po torinese. St Trent Sc Nat 87:179-180.

Dieperink C (1995) Depredation of commercial and recreational fisheries in a Danish fjord by cormorants, Phalacrocorax carbo sinensis, Shaw. Fisheries Manag Ecol 2:197-207.

Fochetti R (2012) Italian freshwater biodiversity: status, threats and hints for its conservation. It J Zool 79:2-8.

Forneris G, Pascale M, Perosino GC, Zaccara P (2011) Stato dell'ittiofauna in Piemonte. Riv Piem St Nat 32:273-295. 
Gagliardi A, Martinoli A, Preatoni D, Wauters LA, Tosi G (2007) From mass of body elements to fish biomass: a direct method to quantify food intake of fish eating birds. Hydrobiologia $583: 213-222$.

Gandolfi G, Zerunian S, Torricelli P, Marconato A (1991) I Pesci delle acque interne italiane. Ministero dell'Ambiente, Unione Zoologica Italiana. Istituto Poligrafico e Zecca dello Stato, Roma, Italy.

Grémillet D, Enstipp MR, Boudiffa M, Liu H (2006) Do cormorants injure fish without eating them? An underwater video study. Marine Biol 148:1081-1087.

Keller T(1995) Food of Cormorants Phalacrocorax carbo sinensis wintering in Bavaria (South of Germany). Ardea 83:185-912.

Kloskowski J (2011) Human-wildlife conflicts at pond fisheries in eastern Poland: perceptions and management of wildlife damage. Eur J Wildl Res 57:295-304

Kottelat M, Freyhof J (2007) Handbook of European freshwater fishes. Kottelat, Cornol Switzerland and Freyhof, Berlin, Germany.

Jepsen N, Olesen T (2006) Cormorants in Denmark - re-enforced management and scientific evidence. Reconciliation action plans for targeted conflicts. FRAP Project EU, WP11-D21.

Leopold MF, van Damme CJ, van der Veer HW (1998) Diet of cormorants and the impact of cormorant predation on juvenile flatfish in the Dutch Wadden Sea. J Sea Res 40:93-107.

Lucentini L, Palomba A, Lancioni H, Gigliarelli L, Natali M, Panara F (2006) Microsatellite polymorphism in Italian populations of northern pike (Esox Lucius L). Fish Res 80:251-262.

Marion L, Le Gentil J (2006) Ecological segregation and population structuring of the Cormorant Phalacrocorax carbo in Europe, in relation to the recent introgression of continental and marine subspecies. Evol Ecol 20:193-216.

Ondračková M, Valová Z, Kortan J, Vojtek L, Adámek Z (2012). Consequent effects of the Great Cormorant (Phalacrocorax carbo sinensis) predation on parasite infection and body condition of common carp (Cyprinus carpio). Parasitol. Res.10:1487-1493. 
Opačak A, Florijančić T, Horvat D, Ozimec S, Bodakoš S (2004) Diet spectrum of great cormorants

(Phalacrocorax carbo sinensis L.) at the Donji Miholjac carp fishponds in eastern Croatia. Eur J Wildlife Res 50: 173-178

Penczak T, Głowacki $Ł$ (2008). Evaluation of electrofishing efficiency in a stream under natural and regulated conditions. Aquat Living Resour, 21: 329-337.

Poór C (2005) The influence of cormorant (Phalacrocorax carbo Linné, 1758.) on fish population in open waters in Hungary. page 6 in: Topical problems in water ecosystems protection, Abstract Book, Průhonice, Czech Republic.

Puzzi CM, Romano C, Sartorelli M, Gentili G, Barenghi B, Bendotti R (2012). Realizzazione di habitat lacustri sommersi nei laghi insubrici. Page 19 in Proceedings of the 24st National AIIAD Congress, AIIAD, Torino, Italy.

Regione Piemonte (1992) Carta ittica relativa al territorio della regione piemontese. Regione Piemonte, Assessorato Caccia e Pesca, Torino.

Regione Piemonte (2006). Monitoraggio della fauna ittica in Piemonte. Direzione Pianificazione delle Risorse Idriche, Torino.

Rondinini C, Battistoni A, Peronace V, Teofili C (2013) Lista Rossa IUCN dei Vertebrati italiani. Comitato italiano IUCN e Ministero Ambiente Tutela Territorio Mare, Roma, Italy.

Russell I, Parrott D, Ives M, Goldsmith D, Fox S, Clifton-Dey D, Drew T (2008) Reducing fish losses to cormorants using artificial fish refuges: an experimental study Fisheries Manag Ecol 15:189-198.

Salvadori T (1872) Fauna d'Italia. Uccelli. Vallardi, Milano, Italy.

Santoul F (2005) The diet of Great Cormorants Phalacrocorax carbo wintering in South-Western France. Rev Ecol - Terre Vie 60:83-87.

Spairani M, Stellin D, Vezza P, Calles O, Comoglio C (2010) Incidenza della predazione del cormorano, rilevata tramite radiotracking, su popolazioni di Salmonidi in un tratto di Dora 
Baltea in Valle d'Aosta. Page 42 in Proceedings of the 13st National AIIAD Congress. AIIAD, Sansepolcro, Italy.

Steffens W (2010) Great Cormorant - substantial danger to fish populations and fishery in Europe. Bulg J Agrl Science 16:322-331.

Van Bommel S (2003) Social causes of the Cormorant revival in Netherlands. Corm Res Group Bull 5:16-24.

Van Eerden MR, Gregersen J (1995) Long-term changes in the Northwest European population of Cormorants Phalacrocorax carbo sinensis. Ardea 83:61-79.

Van Eerden MR, van Rijn S, Keller V (2011) Proceedings 7th International Conference on Cormorants, Villeneuve, Switzerland 23-26 November 2005. Wetlands International-IUCN Cormorant Research Group, Lelystad.

Van Eerden M, van Rijn S, Volponi S, Paquet JY, Carss D (2012) Cormorants and the European Environment: exploring cormorant ecology on a continental scale. Cost Action 635 Final Report I.

Vetemaa M, Eschbaum R, Albert A, Saks L, Verliin A, Jürgens K, Saat T (2010) Changes in fish stocks in an Estonian estuary: overfishing by cormorants? ICES J Mar Sci 67:1972-1979.

Volponi S, CorMoNet.it (2013) Status of the breeding population of Great Cormorants in Italy. Danish Centre for Environment and Energy report 22:59-64.

Wilkinson L. (1992) SYSTAT Version 8.0. Systat Inc. Evanston, Illinois. 


\begin{tabular}{|c|c|c|c|c|c|c|}
\hline Id & Name & Coordinates & $\begin{array}{l}\text { Altitude } \\
\text { a.s.l.s }\end{array}$ & $\begin{array}{l}\text { Area (ha) } \\
\text { (ha) }\end{array}$ & $\begin{array}{l}\text { Depth } \\
\text { (m) }\end{array}$ & $\begin{array}{l}\text { Pike } \\
\text { specimens }\end{array}$ \\
\hline 1 & Escosa & $44^{\circ} 56^{\prime} 20^{\prime \prime} \mathrm{N} 7^{\circ} 40^{\prime} 48^{\prime \prime} \mathrm{E}$ & $229 \mathrm{~m}$ & 40.0 & 50 & 27 \\
\hline 2 & Ceretto & $44^{\circ} 51^{\prime} 41^{\prime \prime} \mathrm{N} 7^{\circ} 39^{\prime} 42^{\prime \prime} \mathrm{E}$ & $236 \mathrm{~m}$ & 30.3 & 55 & 13 \\
\hline 3 & Germaire & $44^{\circ} 51^{\prime} 39^{\prime}{ }^{\prime} \mathrm{N} 7^{\circ} 40^{\prime} 18^{\prime \prime} \mathrm{E}$ & $234 \mathrm{~m}$ & 30.0 & 55 & 46 \\
\hline 4 & Monviso & $44^{\circ} 49^{\prime} 11^{\prime \prime} \mathrm{N} 7^{\circ} 36^{\prime} 47^{\prime \prime} \mathrm{E}$ & $241 \mathrm{~m}$ & 13.5 & 40 & 02 \\
\hline 5 & Fontane & $44^{\circ} 48^{\prime} 57^{\prime \prime} \mathrm{N} 7^{\circ} 34^{\prime} 43^{\prime \prime} \mathrm{E}$ & $243 \mathrm{~m}$ & 22.6 & 40 & 51 \\
\hline
\end{tabular}

Table 1: Main characteristics of gravel pit lakes in the study area

\section{Figure captions}

Fig. 1. Approximate winter (November-January) distribution of Phalacrocorax carbo sinensis in Piemonte (NW Italy): A) years 1986-1992 (from Cucco et al. 1996); B) years 2006-2012.

Fig. 2. Monthly distribution of Cormorant density in the study area. Horizontal bar displays the Cisalpine Pike reproductive period.

Fig. 3. Superficial (A), deep (B, C) and a combination of both wound types (D) caused by Cormorant attacks on Cisalpine Pikes. 
Click here to download Figure: Fig_1.tif
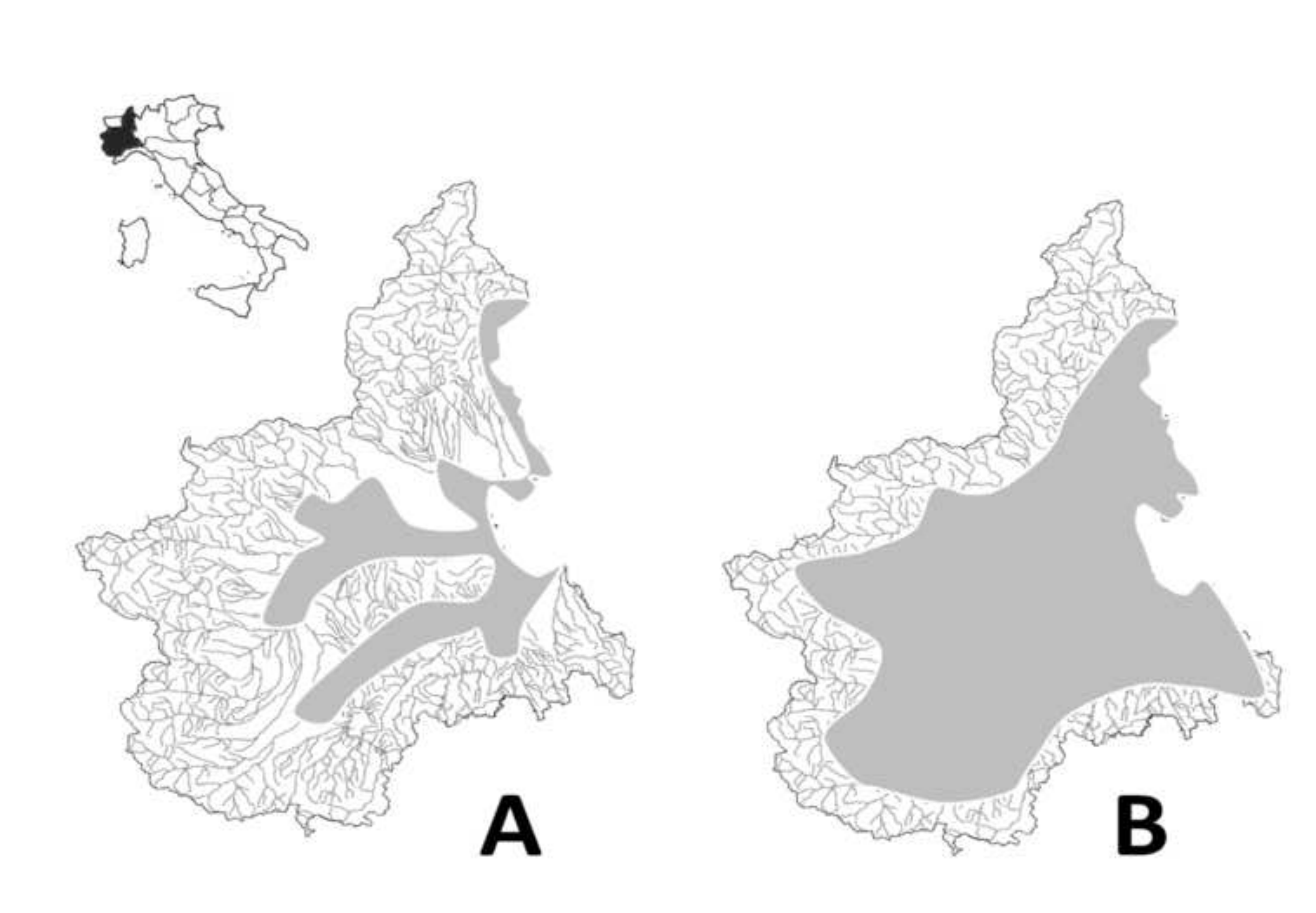

A

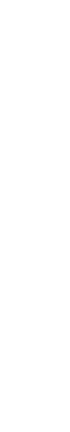

.

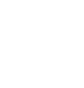

.

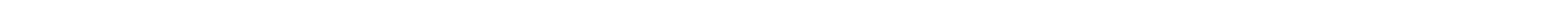


Click here to download Figure: Fig_2.tif

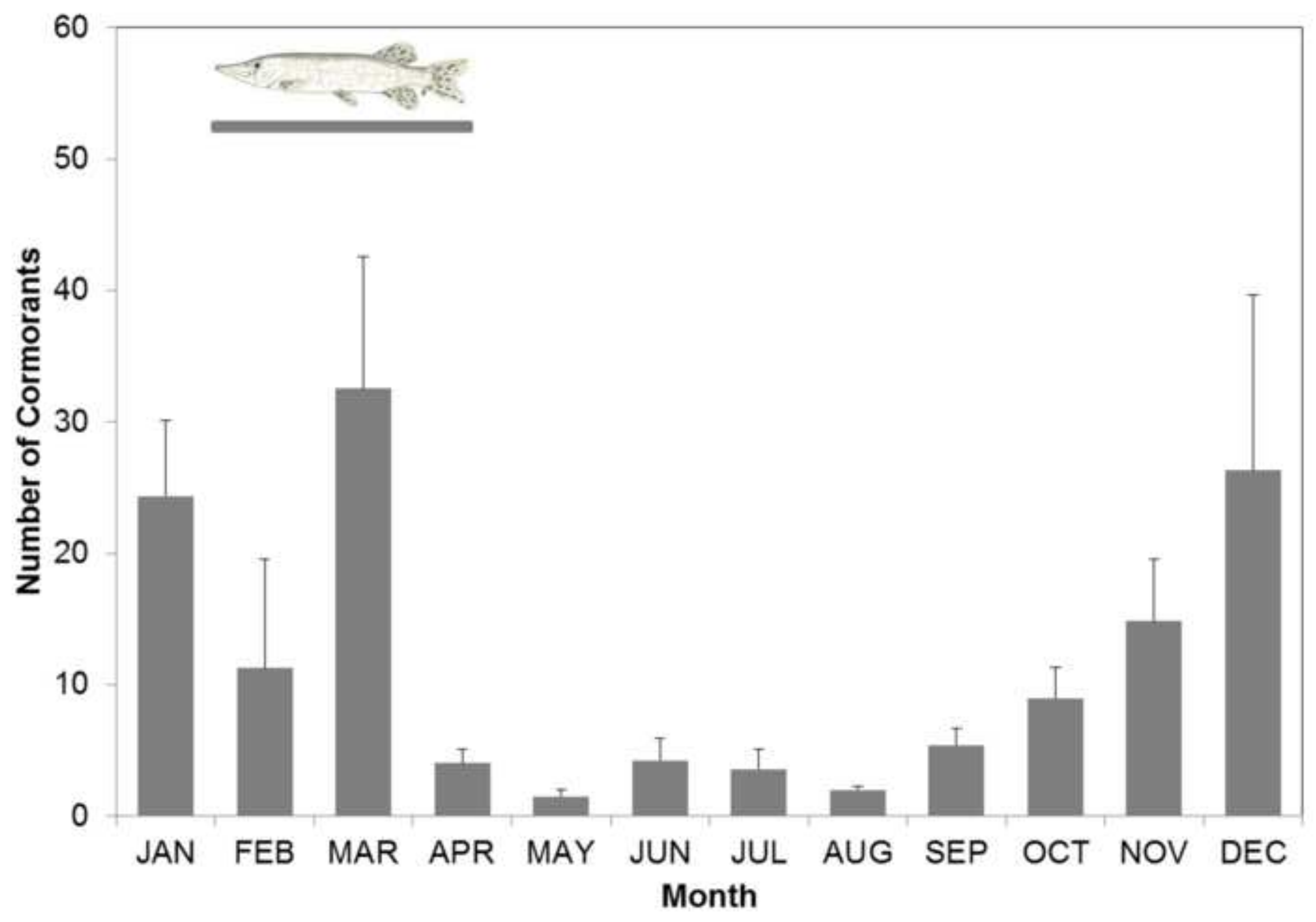


Click here to download Figure: Fig_3.tif
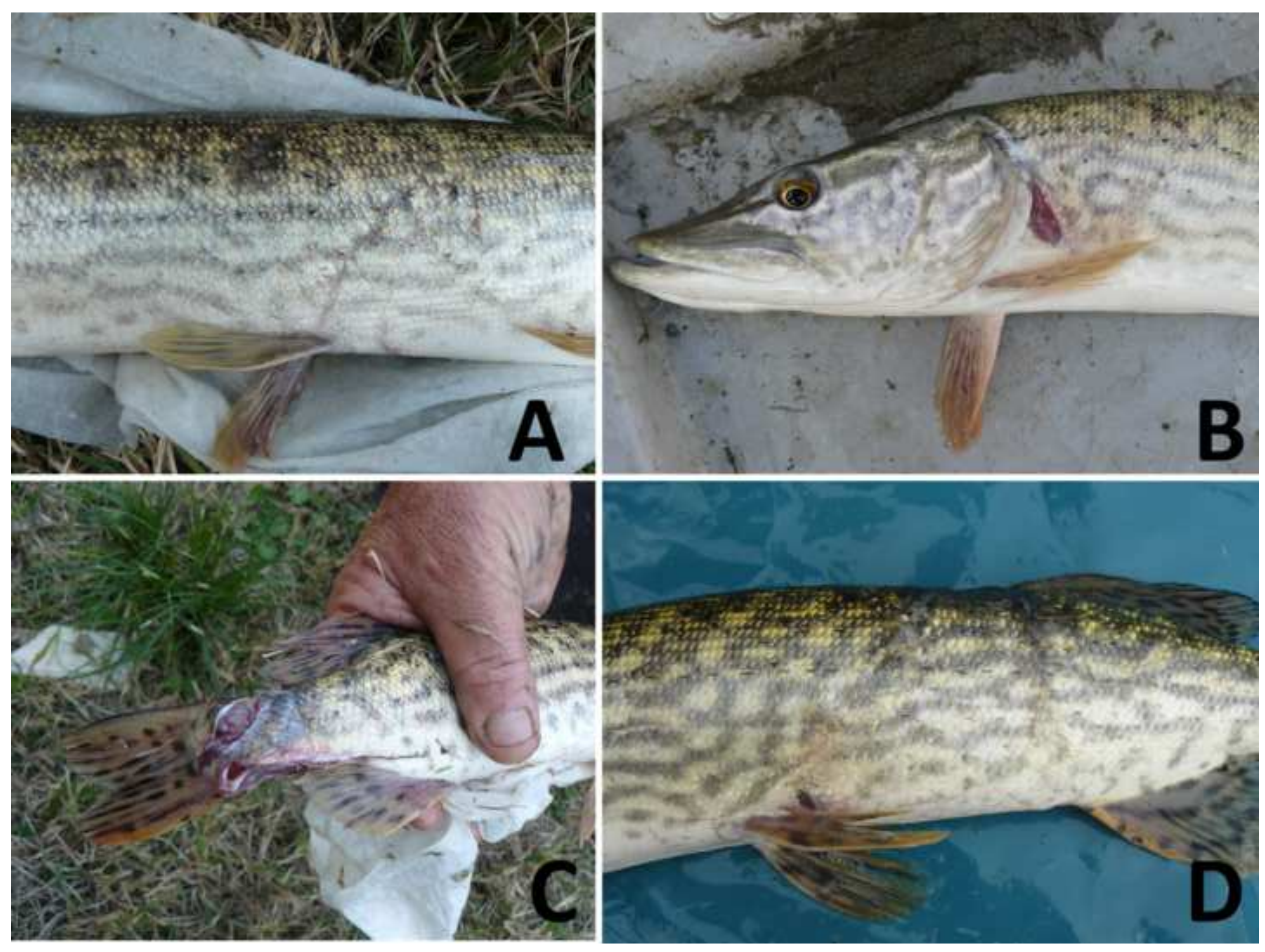


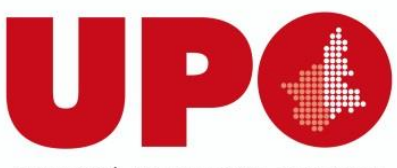

UNIVERSITÀ DEL PIEMONTE ORIENTALE

\section{Università del Piemonte Orientale}

Di.S.I.T.

Via Teresa Michel 11, - 15121

Alessandria

Tel. +39.131.360201 - Fax +39.131.360243

e-mail: fenoglio@unipmn.it

Alessandria, 16/07/2015

Subject: Responses to the second round of comments Ms EJWR-D-14-00254

Dear Editor,

in this second round we were only asked to do some grammatical corrections.

We made all the corrections indicated and we also thoroughly checked the text and corrected the English

Thanks again

Sincerely yours, Stefano Fenoglio 